ЕМИЛИЯ НЕДКОВА

ФАКУЛТЕТ ПРИРОДНИ НАУКИ И ОБРАЗОВАНИЕ

РУСЕНСКИ УНИВЕРСИТЕТ „АНГЕЛ КЪНЧЕВ“

РУСЕ, БъЛГАРИЯ

prevned@abv.bg

https://doi.org/10.17234/9789531755139.21

\title{
ЛИНГВИСТИЧНИ, КУЛТУРОЛОГИЧНИ И ПРАГМАТИЧНИ ПАРАМЕТРИ НА СЪПОСТАВИТЕЛНОТО ИЗСЛЕДВАНЕ НА БЪЛГАРСКИ И СРЪБСКИ АНИМАЛИСТИЧНИ ФРАЗЕОЛОГИЗМИ
}

\begin{abstract}
Наблюденията показват, че названията на животни се срещат активно като компоненти в множество фразеологизми в славянските езици, чието значение е свързано с характерен образ - на широк крьг представители на животинския свят (диви и домашни животни, птици и насекоми). Такива фразеологизми са продуктивни както в българския, така и в сръбския език, като два близкородствени славянски езика, чиято близост освен това се проявява и на балканска основа. Целта на настоящето изследване е да се анализират в съпоставителен план български и сръбски анималистични фразеологизми. Съпоставката е направена в семиотичен план, като се вземат предвид различията в плана на съдържание, в плана на изразяване и в плана на функциониране. С оглед спецификата на анималистичните фразеологизми се прилага специфичен модел, който обединява определени лингвистични, културологични и прагматични параметри на изследването им.
\end{abstract}

Ключови думи: лингвистични, културологичниипрагматичнипараметри; съпоставително изследване на фразеология; анималистични фразеологизми; български и сръбски език

На съвременния етап съпоставителната насока на изследване на фразеологията се превръща във все по-важна задача на модерната лингвистика. Както посочва в книгата си Българска фразеология, известната българска изследователка Кети Ничева, нужно и интересно е

да се правят съпоставки с фразеологията на други езици. При такива съпоставки ще изпъкнат както общите моменти, така и характерните за българския език черти, особено като се има предвид общоизвестното положение, че фразеологията е една от най-специфичните особености на всеки отделен език.

(Ничева 1987: 212).

По-нататък авторката изтъква, че за целта наблюденията върху лексикалните компоненти на фразеологизмите (= фразеологични единици $=\Phi Е)$ са полезни, от една страна, за теорията на фразеологията, а от друга „дават интересни заключения 
относно бита, културата и психологията на народа, който ги е създал” (Ничева 1987: 212).

Такива разсъждения провокират и настоящото изследване, чиято цел е анализ в съпоставителен план на ФЕ с компоненти названия на животни (т.нар. анималистични ФЕ или ФЕ с компоненти зооними ${ }^{1}$ в български и сръбски език.

Наблюденията ни показват, че названията на животни (обозначени както със субстантивни, така и с адвербиални форми) се срещат активно като компоненти в множество ФЕ в славянските езици, чието значение е свързано с характерен образ - на широк кръг представители на животинския свят (диви и домашни животни, птици и насекоми) (вж. Недкова 2011: 37-49; Витанова 2012: 122-191). Такива ФЕ са продуктивни както в българския език (= БЕ), така и в сръбския език (= СЕ) като два близкородствени славянски езика, чиято близост освен това се проявява и на балканска основа.

Значителната употреба на ФЕ с компоненти названия на животни в тези езици е обусловена от нуждите на всекидневното общуване, в което те изпълняват ролята на ярко номинативно - характеризиращо и експресивно средство.

Основният корпус ФЕ (над 1500) е ексцерпиран от: Фразеологичен речник на българския език (т. I, II. София, 1974/75), Нов фразеологичен речник на българския език (София, 1993), Фразеолошки речник српског језика (Нови Сад, 2012), Бугарско-српски речник (Београд, 2000) и е достатъчно представителен за реалистична културно-езикова характеристика.

Теоретичната основа, от която се изхожда при подбора им, е главно по-тясното схващане за фразеологията ${ }^{2}$.

На тази база е формулирана и нашата работна дефиниция за понятието фразеологична единица:

ФЕ е установена в даден речев колектив, свръхсловна, относително устойчива речникова единица, която има сложна (на словосъчетание или на изречение) и разделно оформена структура. Като възпроизводима единица тя се характеризира с единно, цялостно значение, получено в резултат от семантична трансформация между компонентите като цяло. В езика изпълнява номинативно - характеризираща и експресивна функция.

(Недкова 2003: 18; Недкова 2011:10).

1 Както е известно, в езиковедската литература за тези ФЕ се използват различни терминологични названия и липсва терминологично единство (вж. Рак 2007: 13 цит. по Витанова 2012: $125-126)$. Тук употребяваме термините анималистични $Ф E$ и $Ф Е$ с компоненти зооними с идентичнио значение.

2 В научната литература не съществува единно схващане по този въпрос (вж. Недкова 2003: 13-20). Определянето на статута на ексцерпираните единици като ФЕ ( в това число и на преходните ФЕ (=ПФЕ), които също са включени в ексцерпирания материал, е съгласувано с Фразеологичен речник на българския език 1974/75, а на устойчивите сравнения (=УC) с Речник на устойчивите сравнения в БЕ към Устойчивите сравнения в българския език В. Кювлиева-Мишайкова (С., 1986). 
Целесъобразно е съпоставката между анализираните единици да бъде направена в семиотичен план, като се вземат предвид различията в плана на съдържание, в плана на изразяване и в плана на функциониране. Като отправна точка тук приемаме предложения от руския изследовател В. Г. Гак алгоритьм за съпоставителен анализ на библеизмите в руски и френски език (Гак 1997: 55-65). Същият е доказал своята приложимост и при вече проведеното на по-ранен етап от нас съпоставително изследване на ФЕ с компоненти названия на цветове в български и сръбски език (вж. Недкова 2008: 119-125).

С оглед спецификата на изследваните анималистични ФЕ предлагаме адаптиран модел, който обединява определени лингвистични, културологични и прагматични параметри и се характеризира със следните моменти:

I. Съпоставката на ФЕ в БЕ и СЕ в плана на съдържанието ги различава като еквиваленти и аналози;

1.1 Ето и няколко конкретни примера за анималистични ФЕ еквиваленти:

в БЕ: бяла врана ('нещо рядко и необичайно')

в СЕ: бела врана

в БЕ: черен като гарван ('много черен')

в СЕ: ирн као гавран

*

в БЕ: морски вълк ('опитен моряк')

в СЕ: морски вук

*

в БЕ: червен петел ('пожар')

в CE: ирвени петао

в БЕ: нямам ни куче, ни котка ('нищо нямам, много съм беден')

в СЕ: немам ни кучета ни мачета

$*$

в БЕ: храни куче да те лае ('грижа се за някого, когото смятам за близък, а той ми отговаря с лошо“)

в СЕ: храни псето да те олајава

и много други.

Посочените ФЕ, които представляват разнообразни структурно-семантични типове в двата езика, се характеризират с еднакво денотативно значение, напълно или приблизително еднакъв лексикален състав, лексико-граматически показатели, съчетаемост, граматически категории и употребимост - т.е. между ФЕ в съпоставяните езици е налице еквивалентност по всички важни езикови показатели. Цитираните ФЕ са илюстрация за наличието на междуезикова симетрия на формално равнище (вж. Недкова 2003: 72-81).

1.2. В други случаи откриваме фразеологични аналози, за които е характерна пълна или частична замяна на образа, определящ семантиката на ФЕ. Заложени 
в основата на ФЕ (или избрания признак), образите могат да бъдат близки асоциативно или далечни, но логически съотносими (вж. Влахов, Флорин 1990: 85). Така става възможна смисловата еквивалентност, т.е. изразяване на едни и същи значения по различен начин, чрез различни образни асоциации.

Като аналогични могат да бъдат определени следните анималистични ФЕ:

в БЕ: и вълка сит, и агнето здраво ('употребява се, когато някой иска да задоволи едновременно напълно изключващи се интерес')

в СЕ: и вук сит и козе (овце) на броју,

в които константен остава единствено образът на вълка, а другите образи са частично близки или логически съотносими (срв. в БЕ - агне - т.е. малкото на овцата); в СЕ - овцза, коза).

Други примери за фразеологични аналози, при които ярко изпъква разнообразието от образни асоциации (чрез включените образи на животни) в двата езика, са следните:

в БЕ: пускам червената кобила ('предизвиквам пожар')

в СЕ: пуштати црвеног петла

в БЕ: правя от мухата слон ('правя от нещо незначително голям проблем“)

в СЕ: правити от муве коња / вола / медведа

$*$

в БЕ: надувам се като пуйка ('много се възгордявам')

в СЕ: надувати се као жаба

$$
\text { и др. }
$$

1.2.1. Невинаги обаче разлията при аналогичните ФЕ са свързани с компонента зооним, както е при посочените по-горе примери. Понякога разликите могат да засегнат и другите лексикални компоненти на ФЕ, като по този начин се свържат и с някакво допълнително културно-ценностно значение (т.е. и други концептуални различия да станат културно значими).

Например:

в БЕ: имам кокоши ум ('много съм глупав')

в СЕ: имати кокошји мозак (срв. ум (БЕ) / мозак (CE))

в БЕ: гледам като теле в железница ('гледам много глупаво')

в СЕ: гледати као теле у шарена / нова врата (срв. в БЕ - железница; в СЕ - иарена / нова врата).

в БЕ: беден като иъърковна миика ('много беден')

в СЕ: го као чрквени мии (срв. в БЕ - беден; в СЕ - го).

1.2.2. В отделни случаи при наблюдаваните аналогични ФЕ е възможно компонентът зооним въобще да липсва в единия език, което е показателно за наличието на езикова асиметрия. 
Например:

в БЕ: нито кокал гложди, нито другиму го дава ('за човек, който сам не възползва от някаква възможност, но и на другите не позволява')

в СЕ: нит ' пас коску глође, нито другоме даје.

Прави впечатление, че в този случай наличието на лексикален компонент название на животно в сръбската ФЕ способства за засилване на нейната културна значимост.

1.2.3. Разбира се, при една значителна част от ФЕ с компоненти зооними не откриваме въобще съответствие в другия език. Като цяло ексцерпираните български ФЕ се характеризират с по-голямо богатство и разнообразие. С подчертаната експресивност се отличават например българските иронични ФЕ теле отишъл, вол се върнал ('за човек, който никак не се е променил, все си е глупав'), редица диалектни ФЕ (тража от мъртво магаре пльочи ('нищо не върша'), както и ФЕ от типа на клетвите и благословиите (да ти ядат кучета главата ('лоши неща да ти се случват'); да живееш с орлите ('много дълго да живееш'), представляващи интересна психолингвистична особеност на езика ни. Трябва да отбележим, че в $\mathrm{CE}$ подобни фразеологични словосъчетания са сравнително рядко представени или отсъстват според ексцерпираните срьбски източници.

За да обясним всички посочени различия между анализираните единици, е нужно да изтькнем двата основни фактора, които ги определят - обективен и субективен (вж. Гак 1997: 55). Обективният фактор са природните и културните реалности, свойствени за едната страна и отсъстващи в другата.

Субективния фактор пък се проявява в наличието на произволна избираемост, когато едни и същи реалности, еднакво характерни за две култури, намират различна трактовка във фразеологията на двата езика.

II. Втората задача на нашия анализ е да се съпоставят различията в плана на израза във вътрешната форма на аналогични ФЕ, съдържащи компоненти названия на животни. Тези различия могат да бъдат от количествен или от качествен характер.

2.1. В първия случай се наблюдават лексикално-граматически различия, проявяващи се в 2.1.1. добавяне и 2.1.2. изпускане на думи, както и в наложените във връзка с това трансформации в структурата на фразеологичните словосъчетания.

Например:

в БЕ: хитър като лисииа ('много хитър, лукав')

в СЕ: лукав као стари лисаи

в БЕ: лягам с кокошките ('лягам рано')

в СЕ: ићи с кокошима спавати

*

в БЕ: трай коньо за трева зелена ('обикн. в отговор, когато съветват някого да почака да дойдат по-добри дни, а той няма търпение')

в СЕ: чекај коњу док трава нарасте и др. 
Вижда се, че думите могат да бъдат добавяни или изпускани (в единия или другия език), без да се нарушава общият смисъл на словосъчетанието по силата на тяхното семантично излишество.

2.2. Различията между ФЕ, които са от качествен характер, се проявяват в използването на различни граматически форми и думи.

2.2.1. По отношение на граматическите форми най-често срещаните различия са в зависимост от типа на езика - синтетичен или аналитичен (напр. отсъствието на падежни форми в БЕ; отсъствието на членни форми в СЕ и др.)

2.2.2. Друга разлика между съпоставяните ФЕ в граматическо отношение е във връзка с употребата на компонентите им във форми, които се отличават по категорията число (ед. или мн.ч.).

Например:

в БЕ: държа змия в пазвата си ('грижа се за някого като за близък, без да подозирам, че ми е враг')

в СЕ: носити гују у недрима (на прсима)

В този случай асиметричната употреба на съществителните (недра, $n a з в a)$ в СЕ в множествено число се налага от обстоятелството, че (за разлика от БЕ) в него за тези думи липсва форма за единствено число.

Същевременно от посочените по-горе примери става ясно, че в редица случаи граматическите разлики от качествен и количествен характер могат да бъдат съпровождани и от определени лексикални различия (срв. в БЕ / в СЕ змия - гуја = отровна змия и др.).

2.3. Безспорно такива лексикални различия са най-интересни в сыпоставителен план, тъй като са и значително по-често срещани при анализираните ФЕ в сравнение с граматическите. Лексикалните различия, които имат качествен характер, се осъществяват предимно чрез използването на близкозначни форми (синонимия) в двата езика.

2.3.1. Синонимията се проявява чрез използването на различни смислови или стилистични синоними на компонентите на ФЕ (но не само на компонентите зооними) в двата езика.

Например:

в БЕ: ловя мухите ('нищо не правя') бълхи)

в СЕ: требити буве (срв. в БЕ / СЕ - ловя / требити = чистя; мухи / буве =

в БЕ: ни риба, ни рак ('нещо неопределено')

в СЕ: ни риба ни месо (срв. в БЕ / СЕ - рак / месо)

$*$

в БЕ: не ще мачка риба ('употребява се, когато някой лицемерно казва, че не иска нищо')

в СЕ: неће мачка кобасице (срв. в БЕ / СЕ - риба / кобасииа = наденица) 
в БЕ: пускам муха в главата на някого ('внушавам на някого някаква неприятна мисъл $\left.{ }^{6}\right)$

в СЕ: бацити / ставити буву / црва у уво / главу (срв. в БЕ / СЕ пускам / бацитти $=$ хвърлям $/$ ставити $=$ слагам; муха $/$ бува $=$ бълха; ирв =червей; глава $/$ уво).

2.3.2. Както се вижда от последните примери, определени лексикални различия между съпоставяните ФЕ се появяват и като резултат от наличието на различни фразеологични варианти, срещани при ФЕ и в двата езика.

Наличието на значителен брой фразеологични варианти в БЕ и СЕ прави възможна тяхната взаимозаменяемост и обогатява стилистично възможностите и на двата езика.

III. Третият етап от проведения съпоставителен анализ между българските и сръбски анималистични ФЕ е с оглед на тяхната вътрешна форма (= ВФ). Сред анализираните единици откриваме значителен брой устойчиви изрази, които се характеризират с изменения във ВФ, което свидетелства за наличието на определена междуезикова асиметрия между тях. Известно е, че ВФ това е:

образът, залегнал в основата на названието и отразяващ един или няколко от признаците на назовавания обект, посредством който, от една страна, се облекчава обективирането на формираното понятие за обекта, а от друга - се насочва и активизира мисълта на възприемащия към разбиране същността на назовавания обект.

(Русев 1989: 82).

Успоредно с това ВФ на словесния знак насочва към творческия характер на номинацията, към нейната субективност или обективност, както и към националните, историческите и културните особености на мисленето и светогледа на даден народ, който благодарение на възможностите на езика, е в състояние словесно да разчленява и класифицира заобикалящата действителност.

3.1. Ето защо в различните езици в качеството на основа на назоваването могат да бъдат избрани различни черти на една и съща номинация, по силата на която се образуват различни по външа и вътрешна форма ФЕ (Гак 1997: 62).

Например:

в БЕ: прилича ми като на свиня седло ('никак не ми прилича')

в СЕ: пристајати као магарету седло

За означаване на едно и също значение ('никак не ми прилича') в двата езика съществуват аналогични иронични ФЕ. Те се съотнасят с различен образ, който обаче в еднаква степен олицетворява невъзможната, противоестествена комбинация - свинята или магарето да се оседлаят със седло, което и поражда съответното иронично отношение.

Различният образ в двата езика е свързан с различна вътрешна форма.

Известно е, че въпросът за ВФ е пряко свързан с въпроса за значението на ФЕ, 
което не се изразява направо, както е при лексемите, а косвено чрез образ. Освен това при ФЕ, при които образът е ясен за възприемащия, е налице известна двуплановост - това означава възприемане едновременно и на значението на образа, и на значението на самата ФЕ (вж. Ничева 1987: 105).

3.2. За ФЕ е характерна и сетивност, конкретност, която въздейства на въображението и буди определени емоции. Именно тази сетивност, обусловена от значението на образа, дава възможност да се разтълкува съответната ФЕ, т.е. нейната ВФ, свързана с образа. Експресията, произтичаща от конкретния образ, е особено видима при устойчивите сравнения. Например за обозначаване на признака 'много глупав' в българските и сръбските ФЕ са използвани често пъти еднакви зооморфни образи, които са отражение на начина на възприемане на околната действителност от човека:

срв. в БЕ: глупав като кокошка

в СЕ: глуп као кокош

3.3. Успоредно с това в някои ФЕ откриваме и други характерни образи, свойствени за единия език, но неприемливи за другия:

срв. в БЕ: глупав като шиаран / овца

в СЕ: глуп као во / магаре

3.3.1. За обозначаване на признака 'много работлив“ в българските и сръбските ФЕ еднаквите образи са пчела / мравка:

срв. в БЕ: работлив като пчела / мравка

в СЕ: марљив као пчела / мрав

Специфичен образ в СЕ е къртицата:

срв. в СЕ: марљив као кртица

в БE: $\varnothing$

3.3.2. За обозначаване на признака 'много здрав“ пък, покрай сходните образи (срв. бик)

срв. в БЕ: здрав като бик

в СЕ: здрав као бик

и в двата езика откриваме и такива, които можем да определим като националноспецифични

(в БЕ: елен / в СЕ: риба)

срв. в БЕ: здрав като елен

в СЕ: здрав као риба и др. ${ }^{3}$

Различията във ВФ между аналогични анималистични ФЕ (които както вече видяхме са свързани с частичната или пълна замяна на образа в тях) безспорно трябва да се осмислят с тяхната историческа и националнокултурна специфика. Очевидно различните образи, залегнали в посочените ФЕ, свидетелстват за различните националнокултурни асоции в съпоставяните езици. Подобни езикови факти дават основание в тях да се търси проявата на специфични черти на нацио-

Повече по въпроса за националноспецифичните образи в БЕ и СЕ вж. Недкова 2011: 42-48. 
налната култура, тъй като представляват определени стереотипи на народното самосъзнание с цел самоидентификация и ценностна ориентация (Телия 1996: 215).

Като отражение и на нравствените и етични категории и ценностни постановки, заложени в житейската философия на народа - носител на дадения език, и предавани по традиция от поколение на поколение, ФЕ представляват мощен източник на националнокултурна интерпретация. Културната значимост на изследваните анималистични ФЕ, която в значителна степен се свързва с определени национални стереотипни, насочва към лингвокултурните параметри на отношението човек : животно. При това, изхождайки от твърдението, че хората виждат света главно през призмата на своя роден език (вж. Шаповалова 2005). Така от една страна, се очертава връзката между отношението на даден народ към различни представители на животинския свят и човешките качества и поведение, а от друга - изпъква спецификата на изграждащата се, посредством ФЕ като ярки образно мотивирани единици, българска и сръбска езикова картина на света с оглед на културно-ценностните ú доминанти.

IV. Анализираните на четвъртия етап различия в съотношението между форма и съдьржание (с оглед функционирането на ФЕ и в прагматичен аспект) се проявяват в тяхната асиметрия. Това означава, че едни и същи изрази в различните езици придобива 1. различни значения (многозначност) и обратно 2. една и съща ситуация се описва чрез изрази, различни по своя състав, но с еднакво значение (синонимия).

4.1. В първия случай става въпрос за близки по външна форма ФЕ, при които се проявяват определени семантични различия в двата езика.

Например българската ФЕ идвам на бял кон е със значение 'отличавам се, успявам в някакво начинание', а аналогичната сръбска ФЕ доћи на белом коюу (букв. 'идвам със снега') се използва със значение 'когато дойде зимата'.

Или българските ФЕ разигравам си коня, която се тълкува като 'върша произволи“, съпоставена с аналогичната по състав сръбската ФЕ играти коњя, но която се използва със значение 'карам коня на галоп'.

4.2. Синонимията пък се проявява при различни ФЕ, които имат еднакво значение (при различна външна и вътрешна форма).

срв. в БЕ: миша душа, кован заек ('страхливец')

в СЕ: човек жабље крви ('страхливец') *

в БЕ: яхнал е на оса ('много лют, сърдит')

в CE: љуm као рис ('много лют, сърдит') и други, където различията между българските и сръбските ФЕ следва да се възприемат като отражение на различни аспекти на една и съща ситуация.

В резултат на проведения съпоставителен анализ между български и сръбски анималистични ФЕ можем да направим следните основни изводи.

1. В съпоставяните езици такива ФЕ се отличават със значителна продуктивност, като прави впечатление по-голямото богатство и разнообразие на българските ФЕ (съгласно ексцерпираните източници). 
2. Съпоставката на анималистичните ФЕ в двата езика в плана на съдържание ги различава като еквиваленти и аналози, но при една немалка част ФЕ не откриваме съответствия в другия език като проява на езикова асиметрия.

3. Различията между ФЕ, които имат симетричен характер и могат да бъдат качествени или количествени, засягат както лексикалната, така и граматическата структура на ФЕ. Лексико-граматическите различия се проявяват в добавяне или изпускане на думи, или в използване на различни граматични форми. Най-често срещани при анализираните ФЕ са лексикалните различия.

4. Различията във вътрешната форма между тези ФЕ са свързани както с частична, така и с пълна замяна на образа, заложен в основата им. Тези различия са обусловени най-често от наличието на определен културен компонент в значението им, т.е. налице е определена националнокултурна специфика при тях.

5. Разликите в съотношението между форма и съдържание на изследваните ФЕ (като проява на междуезикова асиметрия) се изявяват чрез различни значения, които придобива един и същ израз в двата езика (многозначност) и чрез описание на една и съща ситуация чрез различни по своя състав изрази (синоними) в тях.

6. Установената близост между анималистичните ФЕ в БЕ и СЕ се дължи на факта, че като близкородствени езици и култури те илюстрират редица общи черти и сходства (на славянска и балканска основа), а различията (в това число и националнокултурните) са резултат на обособения езиков развой и различното народностно самосъзнание на българи и сърби.

\section{ЛИТЕРАТУРА}

Vitanova 2012 = Витанова, Марияна. 2012. Човек и свят (лингвокултурологични проучвания). София: Бул-корени.

Vlahov; Florin 1990 = Влахов, Сергей; Флорин, Сидер. 1990. Непреводимото в превода. София: Наука и изкуство.

Gak $1997=$ Гак, В. Г. 1997. Особенности библейских фразеологизмов в русском языке (в сопоставлении с французскими библеизмами). В: Вопросы языкознания. Москва: Издательский дом «Наука».

Kjuvlieva-Mišajkova 1986 = Кювлиева-Мишайкова, Веса. 1986. Устойчивите сравнения в българския език. София: Народна просвета.

Nedkova 2003 = Недкова, Емилия. 2003. Фразеологично богатство в творчеството на Алеко Константинов. Русе: ЛЕНИ-АН.

Nedkova 2008 = Недкова, Емилия. 2008. Фразеологизми, с компоненти названия на цветове в български и сръбски език. В: Изследвания по фразеология, лексикология $и$ лексикография (в памет на проф. д.ф.н. Кети Анкова-Ничева). София: БАН.

Nedkova 2011 = Недкова, Емилия. 2011. Фразеологизмите като знации в езика на култураma. Русе: ЛЕНИ-АН. 
Ničeva 1987 = Ничева, Кети.1987. Българска фразеология. София: Наука и изкуство.

Rusev 1989 = Русев, Руси. 1989. Същност и особености на лексикалната номинация 6 романите на Д. Димов и Г. Караславов. Кандидатска дисертация. В. Търново.

Telija 1996 = Телия, В. Н. 1996. Русская фразеология. Семантический, прагматический и лингвокультурологический аспект. Москва: Школа „Языки русской культуры“.

Šapovalova 2005 = Шаповалова, Н. В. 2005. Национально-языковая картина мира украинского народа. В: Русская словесность в контексте современных процессов. Волгоград: „Волгоградский государственный университет“.

\section{РЕЧНИЦИ}

Ničeva et al. 1974-1975 = Ничева, Кети et al. 1974-1975. Фразеологичен речник на българския език. т. I-II. София: Университетско издателство Св. Климент Охридски.

Ničeva 1993 = Ничева, Кети. 1993. Нов фразеологичен речник на българския език. София: Издателство на Българска академия на науките.

Otašević 2012 = Оташевић, Ђорђе. 2012. Фразеолошки речник српског језика. Нови Сад: Прометеј.

\section{SAŽETAK}

\section{LINGVISTIČKI, KULTUROLOŠKI I PRAGMATIČKI PARAMETRI KONTRASTIVNOG PROUČAVANJA BUGARSKIH I SRPSKIH ANIMALISTIČKIH FRAZEMA}

Proučavanja pokazuju da su nazivi životinja aktivne sastavnice brojnih frazema u slavenskim jezicima, čije je značenje povezano s karakterističnim likom - širokim krugom predstavnika životinjskog svijeta (divljih i domaćih životinja, ptica i kukaca). Takvi su frazemi produktivni kako u bugarskom, tako i u srpskom jeziku, koji ne samo da su usko srodni jezici već svoju bliskost ostvaruju i na balkanskoj osnovi. Cilj je ovoga istraživanja analizirati bugarske i srpske animalističke frazeme na kontrastivnom planu. Usporedba se vrši na semiotičkom planu pa se u obzir uzimaju razlike na planu sadržaja, na planu izraza i na planu funkcioniranja. S obzirom na specifičnost animalističkih frazema primjenjuje se poseban model koji u njihovu proučavanju ujedinjuje određene lingvističke, kulturološke i pragmatične parametre.

Ključne riječi: lingvistički, kulturološki i pragmatički parametri, kontrastivno proučavanje frazeologije, animalistički frazemi, bugarski i srpski jezik 
